\title{
Intermediate Maturing Soybean Produce Multiple Benefits at 1:2 Maize:Soybean Planting Density
}

\author{
Margarida G. Simbine ${ }^{1,2}$, Frederick P. Baijukya ${ }^{3,4}$ \& Richard N. Onwonga ${ }^{1}$ \\ ${ }^{1}$ Department of Land Resources and Agricultural Technology, University of Nairobi, Nairobi, Kenya \\ ${ }^{2}$ Department of Crop Science, Tshwane University of Technology, Pretoria, South Africa \\ ${ }^{3}$ International Center for Tropical Agriculture, Nairobi, Kenya \\ ${ }^{4}$ International Institute of Tropical Agriculture, Dar es Salaam, Tanzania \\ Correspondence: Margarida G. Simbine, Biological Nitrogen Fixation Lab, Department of Crop Science, \\ Tshwane University of Technology, Private Bag X 680, Pretoria 0001, South Africa. E-mail: \\ marg.simbine@gmail.com
}

Received: May 29, 2018

doi:10.5539/jas.v10n9p29
Accepted: July 2, $2018 \quad$ Online Published: August 15, 2018

URL: https://doi.org/10.5539/jas.v10n9p29

\begin{abstract}
A study was conducted to identify the most suitable intercropping arrangement in smallholder farms in Western Kenya. Biomass and $\mathrm{N}$ (nitrogen)-accumulation, $\mathrm{N}_{2}$ fixation and grain yield of maize and soybeans grown as intercrops at three planting densities were assessed. The study was conducted in four seasons. Three soybean varieties, Namsoy 4m, SC Squire and TGx1987-18F, were used in the experiment. Maize: soybean planting densities 1:1 (D1), 1:2 (D2), 1:3 (D3) as well as sole soybean (SS) and sole maize (SM) were tested. Higher biomass, $\mathrm{N}$-accumulation, and $\mathrm{N}$-fixed in the order $3.8 \mathrm{Mg} \mathrm{ha}^{-1}, 260 \mathrm{~kg} \mathrm{ha}^{-1}$ and $161 \mathrm{~kg} \mathrm{ha}^{-1}$ respectively, were recorded in D3 with long maturing variety TGx1987-18F. Conversely, higher soybean grain yield $<2.4 \mathrm{Mg} \mathrm{ha}^{-1}$ was achieved by intermediate maturing SC Squire in D3. The highest maize yield in the intercrop was obtained in D1. $\mathrm{N}$ balance calculations indicated that planting TGx1987-18F resulted in an addition of 6 to $67 \mathrm{~kg} \mathrm{~N} \mathrm{ha}^{-1}$, while SC Squire and Namsoy $4 \mathrm{~m}$ removed 3 to $89 \mathrm{~kg} \mathrm{~N} \mathrm{ha}^{-1}$ when soybean grain was removed from the field. The differences in $\mathrm{N}$ balances between the intercrops depended on the $\mathrm{N}$-fixed and the amount of $\mathrm{N}$ in harvested soybean and maize grain. Greater land equivalent ratio $<1.75$ were obtained with SC Squire and Namsoy $4 \mathrm{~m}$ in D2. We concluded that intermediate maturing soybean have multiple benefits for farmers in Western Kenya at 1:2 maize: soybean planting density provided that the practice is accompanied with good soil and crop management practices.
\end{abstract}

Keywords: soybean-maize intercropping, agricultural intensification, smallholder farmers, soybean varieties, ${ }^{15} \mathrm{~N}$ natural abundance

\section{Introduction}

Intercropping is regarded as an important practice to stabilize yield, improve crop production and environmental quality in regions with risk in production (Juma, Tabo, Wilson, \& Conway, 2013; Vanlauwe et al., 2015). The stability in yield of intercrops is obtained in several ways, most frequently by compensation of yields of individual components (B. Rerkasem, K. Rerkasem, Peoples, Herridge, \& Bergersen, 1988; Waddington, Mekuria, Siziba, \& Karigwindi, 2007). The reasons for increased production of intercrops are different length of vegetation period, various need for resources and different time of using those resources, suitable vertical arrangement of crops leading to better use of light and less intense competition for nutrients and water (Belel, Halim, Rafii, \& Saud, 2014). However, in the highly populated areas in SSA, majority of farmers practice intercropping because of unavailability of land for cropland expansion. Intercropping of legumes and cereals also conserves natural resources and increase economic returns (Juma et al., 2013).

The most reported best combination for intercropping is intercrop of one crop from the cereal family and the one from the legume family, for example, maize and soybean. Cereals have often been found to have better growth and yields when intercropped with $\mathrm{N}_{2}$ fixing legumes (Egbe, 2010; Fukai \& Trenbath, 1993; Layek et al., 2014; Zhang et al., 2015). This trend is attributed to the transfer of symbiotically fixed $\mathrm{N}_{2}$ from legumes to cereals, which can be (i) an indirect transfer, through the decomposition of litter, roots and nodules (Fujita, Ofosu-Budu, 
\& Ogata, 1992); or (ii) through mycorrhizal uptake and translocation (Ofosu-Budu, Fujita, \& Ogata, 1990); or (iii) a direct transfer through the common mycorrhizal networks, which enable linkages to form between the root systems of both mixes of crop species (He, Xu, Qiu, \& Zhou, 2009) as well as (iv) through the rhizodeposition and subsequent uptake of released root exudates (Fujita et al., 1992; Høgh-Jensen \& Schjoerring, 2001; Mahieu et al., 2014). Despite claims for substantial $\mathrm{N}$ transfer from legumes crops to the associated cereal crops, benefits are insufficient to meet the requirement of intercropped cereal (Giller, 2001). According to Ledgard, Giller, and Bacon (1995), the benefits from $\mathrm{N}$ contribution by legumes are more likely to occur to subsequent crops as the main transfer pathway is due to root and nodule senescence and fallen leaves.

Another advantage of intercropping cereals and legumes is the more efficient utilization of resources such as light, water and nutrients over time and space, leading to increased productivity compared with each sole crop of the mixture (Agegnehu, Ghizaw, \& Sinebo, 2008; Mucheru-Muna et al., 2010; Willey, 1979; Zhang \& Li, 2003). Increased productivity is attributed to factors such as (i) maintained light absorption rate over a longer period (Stern, 1993); (ii) reduced evapotranspiration rate due to higher leaf area per ground area provided by the legume (Anglade, Billen, \& Garnier, 2015); (iii) increased availability of water in the root zones because of deeper penetrating roots of legumes (Giller, 2001) and (iv) promoted $\mathrm{N}$ uptake, utilization and photosynthetic efficiency of cereals (Tsubo, Walker, \& Mukhala, 2001; Zhang et al., 2015).

Despite the many benefits, intercropping of cereal-legume may lead to reduction in yield of the legume component because of the adverse competitive effects (Willey et al., 1983). The cereal component has often a fast growth rate in the intercrop, height advantage, and a more widespread rooting system which gives it upper hand in competition with associated legume crop (Belel et al., 2014). Greater yield loss of the legume crop may therefore occur due to reduced intensity and quality of solar radiation intercepted by the legume crop canopy during the reproductive period which is an important environmental factor determining yield and yield components of the legume (Biabani, Hashemi, \& Herbert, 2012; Jin, Liu, Wang, \& Herbert, 2003).

Indices such as land equivalent ratio (LER) (Keating \& Carberry, 1993; Smith \& Francis, 1986; Willey, 1979), competition ratio (Rao \& Willey, 1980), intercropping advantage (Banik, Sasmal, Ghosal, \& Bagchi, 2000), and monetary advantage index (Dwivedi et al., 2015), are used to describe competition and economic advantage of intercropping compared to monocropping. In East Asia and West Africa savannah, higher LER ( $>1.0)$, and yield advantage (of 2-63\%), indicating advantage in intercropping, has been reported in maize-soybean intercropping in comparison to monocropping (Layek et al., 2014; Muoneke, Ogwuche, \& Kalu, 2007; Zhang et al., 2015).

Although intercropping of cereals and legumes is widespread among smallholder farmers in SSA (Odendo, Bationo, \& Kimani, 2011), there is limited knowledge on how soybean can best be intercropped with maize to achieve higher nitrogen fixation and yield of both maize and soybean. This is because, in the past, many countries in SSA, including Kenya, gave low priority to soybean research as it was considered a minor crop (J. N. Chianu, Nkonya, Mairura, J. N. Chianu, \& Akinnifesi, 2010). In the meantime, soybean is gaining a changing strategic importance, firstly as a key protein source in the booming animal feed industry and secondly as a commodity for human nutrition and income (Chianu et al., 2010), demanding for innovations to increase its productivity. This paper reports results of the study conducted in Western Kenya with the objectives to (i) assess biomass accumulation and nitrogen fixation of soybean varieties intercropped with maize at different planting densities, (ii) determine yields of maize and soybean intercropped at different planting densities; and (iii) assess the benefits of intercropping soybean and maize at different planting densities under smallholder farmers' conditions.

\section{Materials and Methods}

\subsection{Description of Study Sites}

The study was carried out in Western Kenya, at Lubino and Manyala villages and was maintained on the same sites for 4 seasons namely the short rainy seasons of 2012 and 2013 and the long rainy seasons of 2013 and 2014 The two sites are separated by a distance of about $50 \mathrm{~km}$. Manyala is found in Butere District located at $0.971^{\circ} \mathrm{N}$ and $34.274^{\circ} \mathrm{E}, 1363 \mathrm{~m}$ altitude. Lubino is found in Mumias District located at $0.312^{\circ} \mathrm{N}$ and $34.565^{\circ} \mathrm{E}, 1372 \mathrm{~m}$ altitude. The rainfall pattern in Western Kenya is bimodal with two distinct rainy seasons; the long rainy season starting in March ending June and short rainy season starting in October ending December. Annual average rainfall in Western Kenya ranges from $900 \mathrm{~mm}$ to $2200 \mathrm{~mm}$. Temperatures range from a minimum of $14{ }^{\circ} \mathrm{C}$ to a maximum of $36^{\circ} \mathrm{C}$ throughout the year (Jaetzold \& Schmidt, 2005). According to the same authors the soils at Lubino and Manyala are classified, respectively, as Humic nitisols and Orthic ferralsols. 


\subsubsection{Weather Conditions During the Study Period}

During the study period, the rainfall was recorded daily at all sites using portable rain gauges. The four seasons of the study experienced very different growing conditions (Figure 1). The 2012 short rainy season was excellent for the experiment, but dry spell followed through mid- November and January 2013 when soybean was setting pods (Figure 1a). The 2013 long rainy season was exceptional. The first half of March was dry, resulting in later than normal planting in April (Figure 1b). The planting conditions in 2013 short rainy season were excellent for establishing the experiments, but prolonged dry spell occurred throughout December, which affected the crop at Lubino site (Figure 1c). The 2014 long rainy season was unique with much rain than normal (Figure 1d). The season was cool, and the overall performance of the crop was good. The cumulative rainfall during the study period was 933 and $853 \mathrm{~mm}$ during the short rainy season of 2012 and 1368 and $1199 \mathrm{~mm}$ during the 2013 long rainy season in Manyala and Lubino, respectively. During the short rainy season of 2013, 892 and $1256 \mathrm{~mm}$ was recorded while in the long rainy season of 2014, 1801 and $3295 \mathrm{~mm}$ was recorded in Manyala and Lubino respectively (Figures 1a-1d).
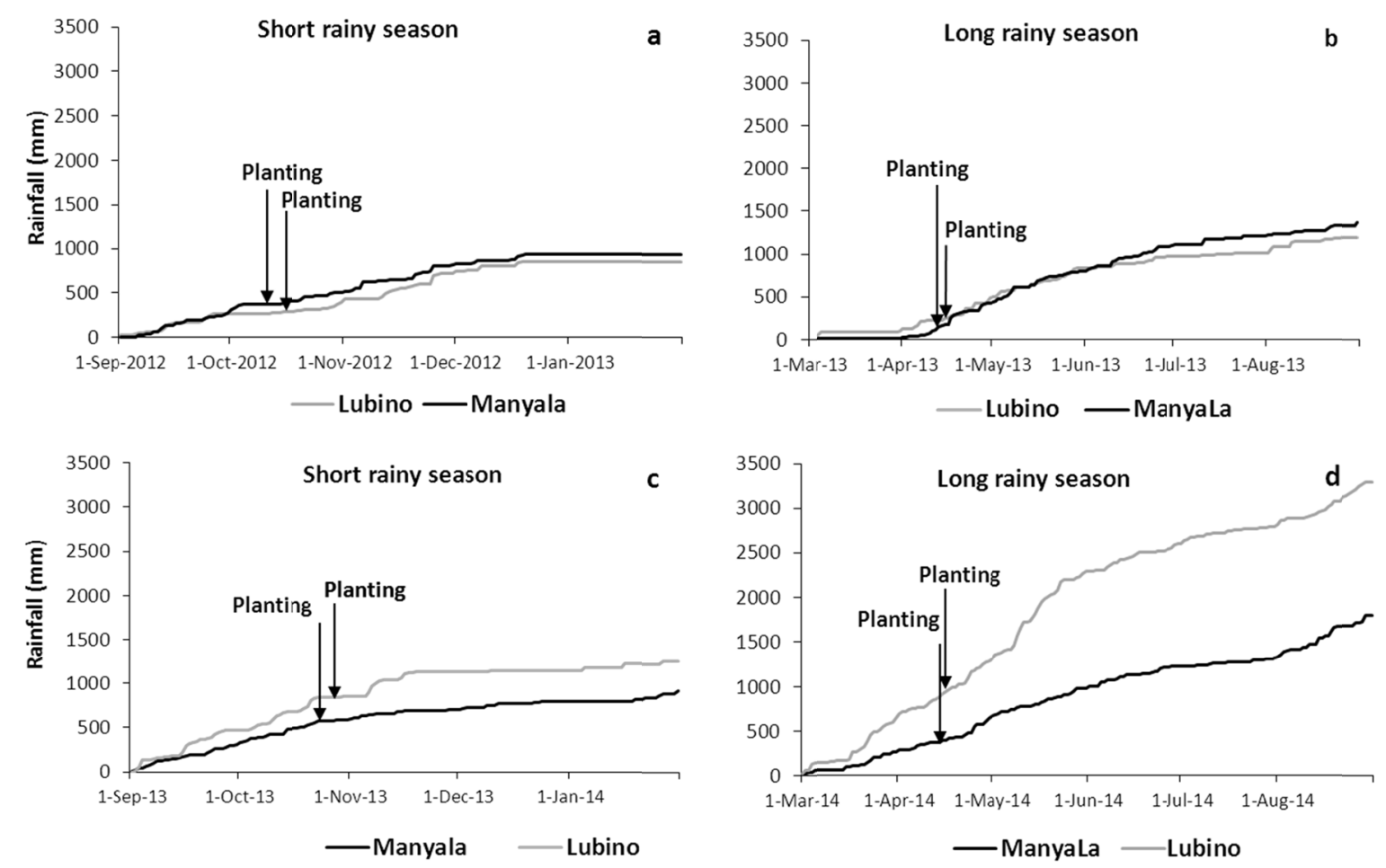

Figure 1. Cumulative daily rainfall during the experimental periods as recoded in 2012 short rainy season (a), 2013 long rainy season (b), 2013 short rainy season (c) and 2014 long rainy season (d) as recorded at Manyala and Lubino sites

\subsubsection{Soil Characterization}

At the beginning of the experiment in 2012, composite top-soil of nine to twelve samples were collected from each site from 0-20 cm layer in a zigzag manner using a $5 \mathrm{~cm}$ diameter soil auger. Samples were air-dried and ground to pass a $2 \mathrm{~mm}$ sieve. The soils were analyzed for physical and chemical properties at the International Centre for Tropical Agriculture (CIAT) soil laboratory in Nairobi, Kenya, following procedures described in Okalebo, Gathua, and Woomer (1993). Soil pH was determined in a soil:water (1:2.5) suspension. The Bray 2 method was used to determine available P and the Kjeldahl method for total N. Walkley Black method was used to determine organic $\mathrm{C}$ and the ammonium acetate method for $\mathrm{CEC}$ and exchangeable cations $(\mathrm{K}, \mathrm{Ca}$ and $\mathrm{Mg})$. Exchangeable $\mathrm{Al}, \mathrm{B}, \mathrm{Zn}, \mathrm{Cu}$ and $\mathrm{Fe}$ and available molybdenum (Mo) were analyzed based on Mehlich 3 extraction procedure (Mehlich, 1984). Particle size distribution was determined using the hydrometer method and the textural class of the soil was determined using the USDA textural triangle. 
Soil data from experimental fields showed wide variability in major properties with soil at Lubino being strongly acidic, low in total $\mathrm{N}$ and exchangeable $\mathrm{Mg}$ (Table 1). The soil at Manyala was slightly acidic with moderate levels of exchangeable Mg. Both soils had moderate levels of organic C (2.4-2.5 g kg-1), but were low in total N, exchangeable $\mathrm{K}$ and $\mathrm{Ca}$. Available $\mathrm{P}$ in both soils was far below the critical value for maize and soybean of $<15$ $\mathrm{mg} \mathrm{kg}^{-1}$ (Nandwa \& Bekunda, 1998), but micronutrients $\mathrm{Zn}, \mathrm{Cu}, \mathrm{B}$ and Mo were in sufficient range (Landon, 1991). The sandy clay loam soil at Lubino site had high levels of exchangeable $\mathrm{Al}$ and $\mathrm{Fe}$, when compared to a clayey textured soil at Manyala site.

Table 1. Physico-chemical properties of the surface soil $(0-20 \mathrm{~cm})$ at the experimental sites

\begin{tabular}{|c|c|c|}
\hline \multirow{2}{*}{ Characteristic } & \multicolumn{2}{|c|}{ Site } \\
\hline & Lubino & Manyala \\
\hline $\mathrm{pH}(1: 2.5$ Water $)$ & 5.2 & 5.7 \\
\hline Available $\mathrm{P}\left(\mathrm{mg} \mathrm{kg}^{-1}\right)$ & 2.4 & 7.9 \\
\hline Total $\mathrm{N}\left(\mathrm{g} \mathrm{kg}^{-1}\right)$ & 0.1 & 0.2 \\
\hline Organic $\mathrm{C}\left(\mathrm{g} \mathrm{kg}^{-1}\right)$ & 2.5 & 2.4 \\
\hline C.E.C (meq/100 g) & 6.8 & 9.3 \\
\hline Exchangeable $\mathrm{K}\left(\mathrm{cmol}_{\mathrm{c}} \mathrm{kg}^{-1}\right)$ & 0.1 & 0.1 \\
\hline Exchangeable $\mathrm{Ca}\left(\mathrm{cmol}_{\mathrm{c}} \mathrm{kg}^{-1}\right)$ & 1.3 & 1.1 \\
\hline Exchangeable $\mathrm{Mg}\left(\mathrm{cmol}_{\mathrm{c}} \mathrm{kg}^{-1}\right)$ & 0.1 & 0.2 \\
\hline $\mathrm{Al}\left(\mathrm{mg} \mathrm{kg}^{-1}\right)$ & 980.2 & 660.4 \\
\hline $\mathrm{Zn}\left(\mathrm{mg} \mathrm{kg}^{-1}\right)$ & 69.7 & 57.1 \\
\hline $\mathrm{Cu}\left(\mathrm{mg} \mathrm{kg}^{-1}\right)$ & 8.4 & 11.2 \\
\hline $\mathrm{Fe}\left(\mathrm{mg} \mathrm{kg}^{-1}\right)$ & 389.2 & 189.6 \\
\hline $\mathrm{B}\left(\mathrm{mg} \mathrm{kg}^{-1}\right)$ & 4.0 & 6.8 \\
\hline $\operatorname{Mo}\left(\mathrm{mg} \mathrm{kg}^{-1}\right)$ & 1.2 & 3.6 \\
\hline Sand $(\%)$ & 55.8 & 27.9 \\
\hline Clay $(\%)$ & 25.4 & 47.4 \\
\hline Silt (\%) & 18.8 & 24.7 \\
\hline Textural Class & Sand Clay Loam & Clay \\
\hline
\end{tabular}

\subsection{Treatment and Experimental Design}

To estimate maize and soybean populations that give higher biomass and grain yield in maize-soybean intercrops, three maize: soybean planting densities, coded as 1:1 (D1); 1:2 (D2) and 1:3 (D3) (in which the first number represents lines of maize and second number represents lines of soybean) were considered. Treatments with sole soybean (SS) and sole maize (SM) were also included as controls. The planting densities were evaluated using three soybean varieties namely; Namsoy $4 \mathrm{~m}$ (supplied by Makerere University, Uganda), SC Squire (Supplied by Seed Co. Zimbabwe) and TGx1987-18F (supplied by International Institute of Tropical Agriculture (IITA), Malawi). The tested soybean varieties are well adapted to Western Kenya conditions but differ in growth habit. SC Squire and Namsoy $4 \mathrm{~m}$ are determinate in growth (finish most of their vegetative growth when flowering begins) and have intermediate growth duration (90-95 days). The soybean variety Namsoy $4 \mathrm{~m}$ tends to keep more leaves towards maturity when compared to SC Squire. The variety TGx1987-18F is indeterminate (continues with vegetative growth after flowering begins) and takes longer to mature ( $>110$ days).

To avoid the impact of Striga (a witch weed that is endemic in Western Kenya) on the experiments, an open pollinated (OP) Imidazolinone herbicide resistant maize (IR-maize) variety WS 003 was used. The experimental plots measured $6.5 \times 3 \mathrm{~m}$. The experiment comprised 13 treatments with different populations of maize and soybean (Table 2). 
Table 2. Treatments and their corresponding equivalent plant population on one ha. The treatments arrangement is as it was in one replication

\begin{tabular}{|c|c|c|c|c|c|c|c|}
\hline Treatment no. & $\begin{array}{l}\text { Treatment } \\
\text { Abbreviation* }\end{array}$ & $\begin{array}{l}\text { Planting } \\
\text { density }\end{array}$ & $\begin{array}{l}\text { Soybean } \\
\text { varieties }\end{array}$ & $\begin{array}{l}\text { Maize plants } \\
\text { in } 1 \text { ha }\end{array}$ & $\begin{array}{l}\text { Soybean plants } \\
\text { in } 1 \text { ha }\end{array}$ & $\begin{array}{l}\text { Maize spacing } \\
\text { (between and within row) }\end{array}$ & $\begin{array}{l}\text { Net plot } \\
\text { (harvested area) }\end{array}$ \\
\hline 1 & D1 & $1: 1$ & Namsoy $4 \mathrm{~m}$ & 53.330 & 266.660 & $0.75 \times 0.25$ & $4.5 \times 2.0 \mathrm{~m}$ \\
\hline 2 & D1 & $1: 1$ & SC Squire & 53.330 & 266.660 & $0.75 \times 0.25$ & $4.5 \times 2.0 \mathrm{~m}$ \\
\hline 3 & D1 & $1: 1$ & TGx1987-18F & 53.330 & 266.660 & $0.75 \times 0.25$ & $4.5 \times 2.0 \mathrm{~m}$ \\
\hline 4 & D2 & $1: 2$ & Namsoy $4 \mathrm{~m}$ & 33.330 & 333.330 & $1.2 \times 0.25$ & $4.5 \times 2.5 \mathrm{~m}$ \\
\hline 5 & D2 & $1: 2$ & SC Squire & 33.330 & 333.330 & $1.2 \times 0.25$ & $4.5 \times 2.5 \mathrm{~m}$ \\
\hline 6 & $\mathrm{D} 2$ & $1: 2$ & TGx1987-18F & 33.330 & 333.330 & $1.2 \times 0.25$ & $4.5 \times 2.5 \mathrm{~m}$ \\
\hline 7 & D3 & $1: 3$ & Namsoy $4 \mathrm{~m}$ & 24.240 & 363.630 & $1.65 \times 0.25$ & $3.3 \times 2.0 \mathrm{~m}$ \\
\hline 8 & D3 & $1: 3$ & SC Squire & 24.240 & 363.630 & $1.65 \times 0.25$ & $3.3 \times 2.0 \mathrm{~m}$ \\
\hline 9 & D3 & $1: 3$ & TGx1987-18F & 24.240 & 363.630 & $1.65 \times 0.25$ & $3.3 \times 2.0 \mathrm{~m}$ \\
\hline 10 & SS & Sole soybean & Namsoy $4 \mathrm{~m}$ & - & 444.440 & - & $4.5 \times 2.5 \mathrm{~m}$ \\
\hline 11 & SS & Sole soybean & SC Squire & - & 444.440 & - & $4.5 \times 2.5 \mathrm{~m}$ \\
\hline 12 & SS & Sole soybean & TGx1987-18F & - & 444.440 & - & $4.5 \times 2.5 \mathrm{~m}$ \\
\hline 13 & $\mathrm{SM}$ & Sole maize & - & 53.330 & - & $0.75 \times 0.25$ & $4.5 \times 2.0 \mathrm{~m}$ \\
\hline
\end{tabular}

Note. $* 1: 1(\mathrm{D} 1)=$ One row of maize alternated with one row of soybean; 1:2 (D2) = One row of maize alternated with two rows of soybean; 1:3 (D3) = One row of maize alternated with three rows of soybean; The planted plot size was $6.5 \times 3 \mathrm{~m}$.

The experimental design was a factorial, arranged in a randomized complete block design (RCBD) with three replicates, where maize: soybean planting densities and the soybean varieties were the factors.

\subsection{Establishment of Experiments and Management}

The experiments were established on flat beds prepared using a hand hoe. Before sowing, all plots received a basal application of legume fertilizer "SYMPAL" (NPK 0:25:15) $+10 \mathrm{CaO}+4 \mathrm{~S}+1 \mathrm{Mg}$ ) at a rate of $200 \mathrm{~kg}$ ha' to provide $\mathrm{P}$ at a rate of $22 \mathrm{~kg} \mathrm{ha}^{-1}, \mathrm{~K}$ at a rate of $25 \mathrm{~kg} \mathrm{ha}^{-1}, \mathrm{Ca}$ at a rate of $16 \mathrm{~kg} \mathrm{ha}^{-1}, \mathrm{~S}$ at a rate of $6.4 \mathrm{~kg}$ ha and $\mathrm{Mg}$ at a rate of $1.6 \mathrm{~kg} \mathrm{ha}^{-1}$. For soybean, SYMPAL fertilizer was applied in furrows dug $5 \mathrm{~cm}$ deep, slightly covered with soil to remain $2.5 \mathrm{~cm}$ deep for planting soybean. For maize, SYMPAL was applied in planting holes (approximately $10 \mathrm{~g}$ per planting hole). Plots with SM and D1 treatments received urea fertilizer at a rate of $130 \mathrm{~kg} \mathrm{ha}^{-1}$ targeted to maize, to supply $\mathrm{N}$ at a rate of $60 \mathrm{~kg} \mathrm{~N} \mathrm{ha}^{-1}$ where $20 \mathrm{~kg}$ was applied at planting and the remaining $40 \mathrm{~kg}$ top-dressed, four weeks after crop emergence. Since the population of maize in D2 and D3 was $38 \%$ and $55 \%$ of that of SM, respectively, the required $\mathrm{N}$ dose in D2 and D3 was adjusted to 33 and $23 \mathrm{~kg} \mathrm{~N}$ $\mathrm{ha}^{-1}$, respectively. Soybean seeds were inoculated with rhizobia inoculant BIOFIX (supplied by MEA Kenya Ltd), containing Bradyrhizobium japonicum USDA 110 strain. The inoculant was applied at a rate of $10 \mathrm{~g} \mathrm{~kg}^{-1} \mathrm{seed}$, following a two-step method (Somasegaran \& Hoben, 2012).

In plots receiving D1 treatment, one line of soybean was established between two lines of maize at a spacing of $0.37 \mathrm{~m}$ from the maize lines. In plots receiving D2 treatment, two soybean lines spaced at $0.45 \mathrm{~m}$ from each other were established in between two maize lines maintaining a distance of $0.37 \mathrm{~m}$ from maize lines. In plots receiving D3 treatment, three lines of soybean were established at same spacing as in D2. In plots receiving SS treatment, soybean was planted at a spacing of $0.45 \times 0.05 \mathrm{~m}$, in furrows opened at a depth of $2.5 \mathrm{~cm}$, after application of SYMPAL fertilizer. Maize in SM plots was planted at a spacing of $0.75 \times 0.25 \mathrm{~m}$, by putting two seeds per planting hole, and subsequently thinned to remain one plant per hill two weeks after emergence. In the short rainy season, the sowing was carried out on 13 and 14 October 2012 and on 18 and 19 September 2013 at Manyala and Lubino site, respectively. Sowing in the long rainy season was done on 12 and 14 April 2013 and on 15 and 16 March 2014 at Manyala and Lubino site, respectively. The experimental fields were kept weed free by frequent weeding using a hand hoe.

\subsection{Plant Harvesting, Sampling, Analysis and Calculations}

Harvesting of soybeans to determine their biomass and $\mathrm{N}$ accumulation as well as $\mathrm{N}_{2}$ fixation was done when the variety attained 50\% flowering. Shoots of soybean plants were harvested in each plot from a randomly selected area of $0.5 \mathrm{~m}^{2}$, by cutting the plants at ground level. From each experimental site, additional samples of couch grass (Digitaria scalarum) that germinated and grew during the same period as soybeans, were collected around the experimental fields for use as reference plant to estimate the nitrogen fixation by soybean. The couch grass has slender wiry creeping rootstalks with the rooting depth $(>1 \mathrm{~m})$ and a growth period of 100 days (Heuze, Tran, 
\& Delagarde, 2014), similar to that of soybean varieties tested. Samples of couch grass were collected from 10 positions around the experiment by cutting the grass at ground level then bulked to make a composite sample per location. The shoot samples (soybean and reference plants), were oven-dried at $65^{\circ} \mathrm{C}$ to constant weight and the soybean shoot samples weighed.

Shoot biomass yield of soybeans were calculated using the weights of samples taken from each plot and were expressed in $\mathrm{Mg} \mathrm{ha}^{-1}$. The dry shoot samples, of soybean and couch grass, were ground to $<1 \mathrm{~mm}$ in cyclotech mill in preparation for $\mathrm{N}$ and ${ }^{15} \mathrm{~N}$ analysis at Catholic University at Leuven in Belgium. Analysis of $\delta^{15} \mathrm{~N}$ of couch grass was done in the first two seasons and it was found to be consistent at each site. Hence, the average $\delta^{15} \mathrm{~N}$ of the first two seasons was used to estimate $\mathrm{N}_{2}$ fixation by soybeans in the third and fourth seasons, with the assumption that same signature was maintained. The measured values of shoot biomass and $\% \mathrm{~N}$ were used to estimate the total nitrogen in legume biomass (N-biomass), expressed in $\mathrm{Mg} \mathrm{ha}^{-1}$. The $\% \mathrm{~N}$ derived from $\mathrm{N}_{2}$ fixation (Ndfa) was estimated using ${ }^{15} \mathrm{~N}$ natural abundance method (Unkovich et al., 2008).

$$
\% N d f a=\left(\delta^{15} N \text { ref }-\delta^{15} N \text { leg }\right) /\left(\delta^{15} N \text { ref }-B \text { value }\right) \times 100
$$

Where, $\delta^{15} \mathrm{~N}$ ref is the ${ }^{15} \mathrm{~N}$ natural abundance of shoots of non-N-fixing reference plant, $\delta^{15} \mathrm{~N}$ leg is the ${ }^{15} \mathrm{~N}$ natural abundance of legume (soybean) shoots, and the $B$ value is the ${ }^{15} \mathrm{~N}$ natural abundance of a legume depending solely on $\mathrm{N}_{2}$ fixation for its $\mathrm{N}$ nutrition. A $B$ value of -1.83 was used in calculating $\% \mathrm{Ndfa}$. This value represents the mean $B$ value for soybean based on experiments conducted by six different laboratories (Unkovich et al., 2008). The amount of N-fixed was calculated according to Maskey, Bhattarai, Peoples, and Herridge (2001):

$$
N \text {-fixed }=(\% N d f a / 100) \times \text { legume } N
$$

Where, $\% \mathrm{Ndfa}$ is percentage of nitrogen derived from atmospheric fixation and legume $\mathrm{N}$ is the nitrogen content of soybean shoots.

In the present study, no attempt was made to estimate the $\mathrm{N}$-fixed in soybean roots although studies have shown that roots of nodulating legumes contain substantial amount of fixed nitrogen (Unkovich et al., 2008).

At maturity, soybean and maize from respective treatments were harvested from the net area demarcated after leaving out two rows of maize/soybean on each side of the plot, the first two and the last two maize/soybean plants on each row to minimize possible edge effect. The cobs and pods were then, shelled, grains dried to $12 \%$ moisture content, and weighed. The weight of grains was used to calculate yields from each treatment and results extrapolated per hectare basis, expressed in $\mathrm{Mg} \mathrm{ha}^{-1}$. After harvest, soybean and maize residues in respective plots were ploughed into the soil to avoid removal by farmers or grazing by animals.

The $\mathrm{N}$ balance of intercrops was calculated for the entire one year by subtracting the total $\mathrm{N}$ contained in soybean grain and $\mathrm{N}$ contained in maize grain from the total $\mathrm{N}$-fixed (averages of two short rainy seasons and 2 long rainy seasons). The nitrogen content of soybean was considered to be $6.08 \%$ (based on $38 \%$ protein) and maize $1.52 \%$ (based on $9.5 \%$ protein) (Giller, 2001). The $\mathrm{N}$ balance was then calculated as follows:

$$
N_{\text {balance }}=\sum N_{\text {fixed }}-\sum N_{\text {soybean grain }}+N_{\text {maize grain }}
$$

Where, $\mathrm{N}_{\text {fixed }}$ is $\mathrm{N}$ from $\mathrm{N}_{2}$ fixation, $\mathrm{N}_{\text {soybean grain }}$ is $\mathrm{N}$ in harvested soybean grain and $\mathrm{N}_{\text {maize grain }}$ is $\mathrm{N}$ in harvested maize grain.

The efficiency of the different planting densities (D1, D2 and D3) for the three soybean varieties tested was determined by calculating the land equivalent ratios (LER) as described by (Willey, 1979). The LER of the intercrops or total LER $\left(\mathrm{LER}_{\text {Total }}\right)$ was obtained by summing the LERs for Maize $\left(\mathrm{LER}_{\text {Maize }}\right)$ and for soybean $\left(\mathrm{LER}_{\text {Soybean }}\right)$ :

$$
L E R_{\text {Total }}=L E R_{\text {Maize }}+L E R_{\text {Soybean }}=Y I M / Y S M+Y I S B / Y S S B
$$

Where, YIM and YISB are grain yields per hectare of intercropped maize and soybean respectively, and YSM and YSSB are grain yields per hectare of sole cropped maize and soybean, respectively.

A LER value greater than 1.0 indicates an intercrop advantage relative to sole crop. LER values less than 1.0 indicate an intercrop disadvantage and LER values equal to 1.0 imply no difference between the intercrop and sole crop (Willey, 1979).

\subsection{Statistical Analysis}

Data on biomass accumulation, $\mathrm{N}$-accumulation, $\mathrm{N}$-fixed and grain yield of both maize and soybean were tested for normality and then subjected to analysis of variance (ANOVA) to determine if there were significant differences between planting densities at two locations in the different cropping seasons. The data was averaged 
over 2 short rainy seasons (2012 and 2013) and 2 long rainy seasons (2013 and 2014) per location (as season was considered fixed factor) and the analyses were carried per location and season given the agroecological differences between the two locations (Manyala and Lubino) and weather conditions between the two rainy seasons. The statistical package GenStat version 13 was used. Where significant differences were obtained, the means were separated using Fisher's least significance difference (LSD) at $P \leq 0.05$.

\section{Results}

\subsection{Biomass Yield, $N$-Accumulation and $N_{2}$ Fixation by Soybean}

Shoot biomass varied across planting densities, sites and seasons (Tables 3 and 4). Higher shoot biomass was recorded on SS and tended to decrease with decreasing soybean plant population, but with a few exceptions. At Manyala site for example, in the short rainy season, biomass yield in D3 was 4\% higher than in SS for soybean variety Namsoy 4m, but 13 and 4\% lower for SC Squire and TGx1987-18F, respectively. In D2, a decrease in shoot biomass in the range of 19 to $22 \%$ was recorded while in D1 the reduction was in the range of 43 to $53 \%$ when compared to SS. The same trend was observed at Lubino site where shoot biomass was lower by 22 to $34 \%$ in D3, 31 to $45 \%$ in D2 and 50 to $61 \%$ in D1 relative to SS, across varieties.

In the long rainy season, shoot biomass at Manyala site was reduced by 7 to $26 \%$ in D3, 20 to $37.0 \%$ in D2 and 2 to $53 \%$ in D1 when compared to SS. At Lubino site the decrease ranged between 13 and $30 \%$ in D2 and 28 to $35 \%$ in D1, but an increase in biomass yield of $8 \%$ was recorded in D3 with the varieties Namsoy $4 \mathrm{~m}$ and SC Squire. Overall, the differences in shoot biomass between D2 and D1, D3 and D1, D3 and D2 and between D1, $\mathrm{D} 2$, and D3 relative to SS were small in the long rainy season when compared to the short rainy season. With the exception of Lubino site in the short rainy season, soybean shoot biomass recorded in D3 was not statically different $(P<0.01)$ from that recorded on SS. Soybean varieties exhibited differences in biomass accumulation under different maize-soybean planting densities with the variety TGx1987-18F accumulating more biomass across planting densities, location and seasons, followed by SC Squire and Namsoy 4m accumulating the least. In general, all soybean varieties accumulated more biomass in the short rainy season than in the long rainy season.

Shoot $\mathrm{N}$-accumulation followed the same trend as shoot biomass across seasons and varieties. For example, in the short rainy season at Manyala site, a decrease in the order of 3\% was recorded in D3 when compared to SS, except with the soybean variety Namsoy $4 \mathrm{~m}$, which recorded a $2 \%$ increase. N-accumulation in D2 and D1 decreased between 19 and $22 \%$ and 43 to 53\%, respectively, when compared to SS across varieties. At Lubino site, a decrease in $\mathrm{N}$-accumulation by 22 to $34 \%$ for D3, 30 to $45 \%$ for D2 and 50 to $63 \%$ for D1 relative to SS was recorded in the short rainy season. In the long rainy season, at Manyala site, for D3, a decrease in shoot $\mathrm{N}$-accumulation was in the order of $8 \%$ with TGx1987-18F and 17\% with SC Squire, but an increase of 32\% with Namsoy 4m, for D3 was recorded. Furthermore, a decrease in shoot $\mathrm{N}$-accumulation by 18 to $37 \%$ for D2 and D1, respectively was observed. At Lubino site, across varieties, $\mathrm{N}$-accumulation decreased from 9 to $31 \%$ in D2 and 28 to $34 \%$ in D1 when compared to SS. In general, across varieties, seasons and sites, there were no significant differences between $\mathrm{N}$ accumulated in D3 and SS except for the short rainy season at Lubino site with the varieties Namsoy $4 \mathrm{~m}$ and SC Squire. However, significant differences $(P<0.001)$ were found between $\mathrm{N}$-accumulated in D1 and D2 when compared to SS. Across varieties and seasons, the highest $\mathrm{N}$ accumulation was recorded on SS, with the soybean variety TGx1987-18F accumulating more N.

The highest amount of N-fixed was recorded in SS with the soybean variety TGx1987-18F fixing 95 and $73 \mathrm{~kg}$ $\mathrm{N} \mathrm{ha}^{-1}$ in the short rainy season and 55 and $36 \mathrm{~kg} \mathrm{~N} \mathrm{ha}^{-1}$ in the long rainy season at Manyala and at Lubino site, respectively. No significant differences were found in N-fixed between SS and D3. In general, significant differences $(P<0.001)$ in N-fixed were detected between D1 and D2, D1 and D3, D1 and SS, D2 and SS and between D2 and D3 in the short and long rainy seasons, across sites and varieties. However, in the long rain season, these strong variations in $\mathrm{N}$-fixed could not be detected between the planting densities across sites. In both seasons, at all sites, soybean varieties Namsoy $4 \mathrm{~m}$ and SC Squire accumulated almost the same amount of biomass and nitrogen, and fixed almost the same amount of $\mathrm{N}$ when established at any of the planting densities, D1, D2, D3 or SS. 
Table 3. Above ground biomass accumulation, $\mathrm{N}$ accumulation and $\mathrm{N}$-fixed of tested soybean varieties under different maize-soybean planting densities as recorded at Manyala and Lubino experimental sites; data are means of yields of 2012 and 2013 short rainy seasons

\begin{tabular}{|c|c|c|c|c|c|c|c|c|c|c|}
\hline \multirow{3}{*}{ Location } & \multirow{3}{*}{ Planting Density } & \multicolumn{9}{|c|}{ Soybean variety } \\
\hline & & \multicolumn{3}{|c|}{ Namsoy $4 \mathrm{~m}$} & \multicolumn{3}{|c|}{ SC Squire } & \multicolumn{3}{|c|}{ TGx1987-18F } \\
\hline & & $\begin{array}{l}\text { AGBM } \\
\left(\mathrm{Mg} \mathrm{ha}^{-1}\right)\end{array}$ & $\begin{array}{l}\mathrm{N} \text {-acc. } \\
\left(\mathrm{kg} \mathrm{ha}^{-1}\right)\end{array}$ & $\begin{array}{l}\mathrm{N}-\text { fix. } \\
\left(\mathrm{kg} \mathrm{ha}^{-1}\right)\end{array}$ & $\begin{array}{l}\text { AGBM } \\
\left(\mathrm{kg} \mathrm{h}^{-1}\right)\end{array}$ & $\begin{array}{l}\mathrm{N}-\text { acc. } \\
\left(\mathrm{kg} \mathrm{ha}^{-1}\right)\end{array}$ & $\begin{array}{l}\text { N-fix. } \\
\left(\text { kg ha }^{-1}\right)\end{array}$ & $\begin{array}{l}\text { AGBM } \\
\left(\mathrm{Mg} \mathrm{ha}^{-1}\right)\end{array}$ & $\begin{array}{l}\text { N-acc. } \\
\left(\text { kg ha }^{-1}\right)\end{array}$ & $\begin{array}{l}\text { N-fix. } \\
\left(\mathrm{kg} \mathrm{ha}^{-1}\right)\end{array}$ \\
\hline \multirow[t]{8}{*}{ Manyala } & D1 & 1.6 & 48 & 33 & 1.6 & 51 & 33 & 1.9 & 68 & 46 \\
\hline & D2 & 2.2 & 68 & 47 & 2.6 & 80 & 55 & 3.0 & 109 & 74 \\
\hline & D3 & 2.9 & 86 & 59 & 3.2 & 100 & 65 & 3.8 & 135 & 92 \\
\hline & SS & 2.8 & 84 & 58 & 3.7 & 115 & 75 & 3.9 & 140 & 95 \\
\hline & SM & - & - & - & - & - & - & - & - & - \\
\hline & LSD AGBM & $0.5^{* * *}$ & & & & & & & & \\
\hline & LSDN-acc. & $16^{* * *}$ & & & & & & & & \\
\hline & LSD N-fixed & $11^{* * *}$ & & & & & & & & \\
\hline \multirow[t]{8}{*}{ Lubino } & $\mathrm{D} 1$ & 1.0 & 31 & 21 & 1.3 & 42 & 28 & 1.2 & 42 & 29 \\
\hline & D2 & 1.6 & 50 & 34 & 1.8 & 58 & 39 & 1.8 & 61 & 42 \\
\hline & D3 & 2.1 & 64 & 44 & 2.0 & 64 & 43 & 2.2 & 73 & 50 \\
\hline & SS & 2.7 & 82 & 57 & 2.7 & 83 & 56 & 3.3 & 111 & 76 \\
\hline & SM & - & - & - & - & - & - & - & - & - \\
\hline & LSD AGBM & $0.2 * * *$ & & & & & & & & \\
\hline & LSD N-acc. & $7 * * *$ & & & & & & & & \\
\hline & LSD N-fixed & $5 * * *$ & & & & & & & & \\
\hline
\end{tabular}

Note. AGBM: Above ground biomass accumulation; $\mathrm{N}$-acc.: $\mathrm{N}$ accumulation; $\mathrm{N}$-fix.: $\mathrm{N}$-fixed; LSD = Least significant difference between means, ${ }^{* * *} P<0.001$.

Table 4. Above ground biomass accumulation, $\mathrm{N}$ accumulation and $\mathrm{N}$-fixed of test soybean varieties under different maize-soybean planting densities as recorded at Manyala and Lubino experimental sites; data are means of yields of 2013 and 2014 long rainy seasons

\begin{tabular}{|c|c|c|c|c|c|c|c|c|c|c|}
\hline \multirow{3}{*}{ Location } & \multirow{3}{*}{ Planting Density } & \multicolumn{9}{|c|}{ Soybean variety } \\
\hline & & \multicolumn{3}{|c|}{ Namsoy $4 \mathrm{~m}$} & \multicolumn{3}{|c|}{ SC Squire } & \multicolumn{3}{|c|}{ TGx1987-18F } \\
\hline & & $\begin{array}{l}\text { AGBM } \\
\left(\mathrm{Mg} \mathrm{ha}^{-1}\right)\end{array}$ & $\begin{array}{l}\text { N-acc. } \\
\left(\mathrm{kg} \mathrm{ha}^{-1}\right)\end{array}$ & $\begin{array}{l}\text { N-fix. } \\
\left(\mathrm{kg} \mathrm{ha}^{-1}\right)\end{array}$ & $\begin{array}{l}\text { AGBM } \\
\left(\mathrm{Mg} \mathrm{ha}^{-1}\right)\end{array}$ & $\begin{array}{l}\text { N-acc. } \\
\left(\mathrm{kg} \mathrm{ha}^{-1}\right)\end{array}$ & $\begin{array}{l}\text { N-fix. } \\
\left(\mathrm{kg} \mathrm{ha}^{-1}\right)\end{array}$ & $\begin{array}{l}\text { AGBM } \\
\left(\mathrm{Mg} \mathrm{ha}^{-1}\right)\end{array}$ & $\begin{array}{l}\text { N-acc. } \\
\left(\mathrm{kg} \mathrm{ha}^{-1}\right)\end{array}$ & $\begin{array}{l}\text { N-fix. } \\
\left(\mathrm{kg} \mathrm{ha}^{-1}\right)\end{array}$ \\
\hline \multirow[t]{8}{*}{ Manyala } & D1 & 1.5 & 48 & 32 & 1.3 & 43 & 29 & 1.9 & 61 & 41 \\
\hline & D2 & 1.3 & 44 & 30 & 1.6 & 53 & 35 & 2.4 & 78 & 53 \\
\hline & D3 & 1.9 & 62 & 57 & 2.7 & 87 & 57 & 3.1 & 100 & 68 \\
\hline & SS & 2.5 & 82 & 43 & 3.2 & 104 & 69 & 3.3 & 109 & 73 \\
\hline & SM & - & - & - & - & - & - & - & - & - \\
\hline & LSD AGBM & $0.2 * * *$ & & & & & & & & \\
\hline & LSD N-acc. & $11 * * *$ & & & & & & & & \\
\hline & LSD N-fixed & $8^{* * *}$ & & & & & & & & \\
\hline \multirow[t]{8}{*}{ Lubino } & D1 & 0.8 & 27 & 18 & 1.0 & 35 & 23 & 1.2 & 37 & 26 \\
\hline & $\mathrm{D} 2$ & 0.9 & 25 & 17 & 1.4 & 50 & 34 & 1.6 & 52 & 36 \\
\hline & D3 & 1.4 & 45 & 31 & 2.5 & 92 & 63 & 1.8 & 57 & 40 \\
\hline & SS & 1.3 & 42 & 29 & 2.3 & 71 & 49 & 2.1 & 69 & 46 \\
\hline & SM & - & - & - & - & - & - & - & - & - \\
\hline & LSD AGBM & $0.3^{* *}$ & & & & & & & & \\
\hline & LSD N-acc. & $10^{* *}$ & & & & & & & & \\
\hline & LSD N-fixed & $7 * *$ & & & & & & & & \\
\hline
\end{tabular}

Note. AGBM: Above ground biomass accumulation; $\mathrm{N}$-acc.: $\mathrm{N}$ accumulation; $\mathrm{N}$-fix.: $\mathrm{N}$-fixed; LSD = Least significant difference between means, ${ }^{* *} P<0.01 ; * * * P<0.001$. 


\subsection{Soybean and Maize Grain Yields}

Across sites and seasons, higher yields of soybean were obtained under SS while for maize was obtained under D1 (Tables 5 and 6), with more yield of both crops achieved in the long rainy season. In the short rainy season, soybean grain yield was reduced by $50 \%$ in D1, but $15 \%$ in D2 and D3 across sites and soybean varieties. Clear differences in yield of soybean under different planting densities could be observed in the long rainy season. For example, at Manyala site, a yield reduction of 28, 45 and 58\% was recorded in D3, D2 and D1, respectively. At Lubino site, a yield reduction of 16, 28 and $45 \%$ was recorded in D3, D2 and D1, respectively. Across sites and seasons the planting density D3 with soybean variety SC Squire gave the highest grain yield of 1.2 and $0.7 \mathrm{Mg}$ $\mathrm{ha}^{-1}$ in the short rainy season and 1.8 and $1.5 \mathrm{Mg} \mathrm{ha}^{-1}$ in the long rainy season at Manyala and Lubino sites, respectively. Across sites, seasons and varieties, no significant differences in soybean grain yields could be observed between D3 and SS.

Maize grain yield was affected by planting densities (Tables 5 and 6). Compared to sole maize (SM), a general yield reduction by 40 to $50 \%$ and 20 to $40 \%$ was observed in D3, D2, for Lubino and Manyala site respectively, and similar trend was observed in both short and long rainy seasons. For D1, an increase in maize grain yield of up to $7 \%$ was recorded. No significant differences in maize grain yields could be observed between D1 and SM, except for Manyala site during the short rainy season and Lubino site in intercrop with Namsoy $4 \mathrm{~m}$ in the same season. Higher yields of maize were recorded in the long rainy season across planting densities, where the intercrops of maize and soybean variety TGx1987-18F gave the highest yield (Table 6).

Table 5. Soybean grain yield and Maize grain yield under different maize-soybean planting densities as recorded at Manyala and Lubino experimental sites; data are means of 2012 and 2013 short rainy seasons

\begin{tabular}{|c|c|c|c|c|c|c|c|}
\hline \multirow[b]{2}{*}{ Location } & \multirow[b]{2}{*}{ Planting Density } & \multicolumn{2}{|c|}{ Maize-Namsoy 4m } & \multicolumn{2}{|c|}{ Maize-SC Squire } & \multicolumn{2}{|c|}{ Maize-TGx1987-18F } \\
\hline & & $\begin{array}{l}\text { SGY } \\
\left(\mathrm{Mg} \mathrm{ha}^{-1}\right)\end{array}$ & $\begin{array}{l}\text { MGY } \\
\left(\mathrm{Mg} \mathrm{ha}^{-1}\right)\end{array}$ & $\begin{array}{l}\text { SGY } \\
\left(\mathrm{Mg} \mathrm{ha}^{-1}\right)\end{array}$ & $\begin{array}{l}\text { MGY } \\
\left(\mathrm{Mg} \mathrm{ha}^{-1}\right)\end{array}$ & $\begin{array}{l}\text { SGY } \\
\left(\mathrm{Mg} \mathrm{ha}^{-1}\right)\end{array}$ & $\begin{array}{l}\text { MGY } \\
\left(\mathrm{Mg} \mathrm{ha}^{-1}\right)\end{array}$ \\
\hline \multirow[t]{7}{*}{ Manyala } & D1 & 0.2 & 1.4 & 0.7 & 1.4 & 0.2 & 1.5 \\
\hline & D2 & 0.4 & 1.1 & 1.1 & 1.1 & 0.2 & 1.2 \\
\hline & D3 & 0.4 & 1.0 & 1.2 & 1.0 & 0.2 & 0.9 \\
\hline & SS & 0.4 & - & 1.4 & - & 0.3 & - \\
\hline & SM & - & 1.8 & - & 1.8 & - & 1.8 \\
\hline & LSD SGY & $0.2^{* *}$ & & & & & \\
\hline & LSD MGY & $0.2 * * *$ & & & & & \\
\hline \multirow[t]{7}{*}{ Lubino } & D1 & 0.1 & 1.2 & 0.3 & 1.9 & 0.4 & 1.9 \\
\hline & D2 & 0.2 & 1.5 & 0.7 & 1.4 & 0.5 & 1.5 \\
\hline & D3 & 0.2 & 1.1 & 0.7 & 1.0 & 0.6 & 1.1 \\
\hline & SS & 0.4 & - & 0.9 & - & 1.2 & - \\
\hline & SM & - & 1.9 & - & 1.9 & - & 1.9 \\
\hline & LSD SGY & $0.1 * * *$ & & & & & \\
\hline & LSD MGY & $0.3 * * *$ & & & & & \\
\hline
\end{tabular}

Note. SGY: Soybean grain yield; MGY: Maize grain yield; LSD $=$ Least significant difference between means, ** $P<0.01$; *** $P<0.001$. 
Table 6. Soybean grain yield and Maize grain yield under different maize-soybean planting densities as recorded at Manyala and Lubino experimental sites; data are means of 2013 and 2014 long rainy seasons

\begin{tabular}{|c|c|c|c|c|c|c|c|}
\hline \multirow[b]{2}{*}{ Location } & \multirow[b]{2}{*}{ Planting Density } & \multicolumn{2}{|c|}{ Maize-Namsoy $4 \mathrm{~m}$} & \multicolumn{2}{|c|}{ Maize-SC Squire } & \multicolumn{2}{|c|}{ Maize-TGx1987-18F } \\
\hline & & $\begin{array}{l}\mathrm{SGY} \\
\left(\mathrm{Mg} \mathrm{ha}^{-1}\right)\end{array}$ & $\begin{array}{l}\mathrm{MGY} \\
\left(\mathrm{Mg} \mathrm{ha}^{-1}\right)\end{array}$ & $\begin{array}{l}\text { SGY } \\
\left(\mathrm{Mg} \mathrm{ha}^{-1}\right)\end{array}$ & $\begin{array}{l}\text { MGY } \\
\left(\mathrm{Mg} \mathrm{ha}^{-1}\right)\end{array}$ & $\begin{array}{l}\mathrm{SGY} \\
\left(\mathrm{Mg} \mathrm{ha}^{-1}\right)\end{array}$ & $\begin{array}{l}\text { MGY } \\
\left(\mathrm{Mg} \mathrm{ha}^{-1}\right)\end{array}$ \\
\hline \multirow[t]{7}{*}{ Manyala } & D1 & 1.1 & 4.5 & 1.0 & 4.5 & 0.8 & 4.7 \\
\hline & D2 & 1.3 & 2.7 & 1.5 & 2.8 & 1.2 & 2.8 \\
\hline & D3 & 1.7 & 2.4 & 1.8 & 2.5 & 1.7 & 2.5 \\
\hline & SS & 2.3 & - & 2.6 & - & 2.4 & - \\
\hline & SM & - & 4.4 & - & 4.4 & - & 4.4 \\
\hline & LSD SGY & $0.1^{* *}$ & & & & & \\
\hline & LSD MGY & $0.3 * * *$ & & & & & \\
\hline \multirow[t]{7}{*}{ Lubino } & $\mathrm{D} 1$ & 0.6 & 2.7 & 0.7 & 1.7 & 0.6 & 3.1 \\
\hline & $\mathrm{D} 2$ & 0.7 & 2.5 & 1.3 & 1.5 & 0.7 & 2.6 \\
\hline & D3 & 0.9 & 2.2 & 1.6 & 1.2 & 0.9 & 2.2 \\
\hline & SS & 0.9 & - & 1.4 & - & 1.0 & - \\
\hline & SM & - & 2.5 & - & 2.5 & - & 2.5 \\
\hline & LSD SGY & $0.2 * * *$ & & & & & \\
\hline & LSD MGY & $0.6^{* * *}$ & & & & & \\
\hline
\end{tabular}

Note. SGY: Soybean grain yield; MGY: Maize grain yield; LSD $=$ Least significant difference between means, ** $P<0.01 ; * * * P<0.001$.

\subsection{Nitrogen Balances of Intercrops}

Net $\mathrm{N}$ balances of intercrops varied from -37 to $+47 \mathrm{~kg} \mathrm{~N} \mathrm{ha}^{-1}$ when only harvest soybean grain was removed and from -107 to $-5 \mathrm{~kg} \mathrm{~N} \mathrm{ha}^{-1}$ when both soybean and maize grain were removed (Table 7). With only soybean grain removed, positive $\mathrm{N}$ balances were recorded at Manyala site in all intercrops with TGx1987-18F, and at Lubino site in D2 with TGx1987-18F and in D3 with Namsoy 4m. Overall, the N balance of intercrops was less negative with increasing soybean plant population, where intercrops with TGx1987-18F had less negative N balances, while the intercrops with SC Squire had more negative $\mathrm{N}$ balances. 
Table 7. Nitrogen balances $\left(\mathrm{kg} \mathrm{ha}^{-1} \mathrm{year}^{-1}\right)$ in maize-soybean intercropping of different planting densities at Manyala and Lubino sites, Western Kenya. Balances are averages of 2012 and 2013 short rainy seasons, and 2013 and 2014 long rainy seasons

\begin{tabular}{|c|c|c|c|c|c|c|c|c|c|c|c|c|c|c|c|c|}
\hline \multirow{3}{*}{ Location } & \multirow{3}{*}{ Planting density } & \multirow{2}{*}{\multicolumn{3}{|c|}{ Total N-fixed }} & \multicolumn{6}{|c|}{ Total $\mathrm{N}$ harvested in grains } & \multicolumn{6}{|c|}{ Net balances } \\
\hline & & & & & \multicolumn{3}{|c|}{ Soybean grain } & \multicolumn{3}{|c|}{ Maize grain } & \multicolumn{3}{|c|}{$\begin{array}{l}\text { Soybean grain } \\
\text { removed }\end{array}$} & \multicolumn{3}{|c|}{$\begin{array}{l}\text { Soybean + maize } \\
\text { gain removed }\end{array}$} \\
\hline & & $\overline{\mathrm{v} 1}$ & v2 & v3 & $\mathrm{v} 1$ & v2 & v3 & v1 & v2 & v3 & $\mathrm{v1}$ & $\mathrm{v} 2$ & v3 & v1 & v2 & v3 \\
\hline \multirow[t]{8}{*}{ Manyala } & D1 & 65 & 93 & 87 & 78 & 108 & 60 & 90 & 92 & 94 & -13 & -15 & +27 & -103 & -107 & -67 \\
\hline & $\mathrm{D} 2$ & 77 & 121 & 127 & 102 & 156 & 84 & 58 & 59 & 61 & -25 & -35 & +43 & -83 & -94 & -18 \\
\hline & D3 & 115 & 143 & 161 & 126 & 180 & 114 & 52 & 53 & 52 & -11 & -37 & +47 & -63 & -90 & -5 \\
\hline & SS & 101 & 151 & 168 & 162 & 240 & 162 & 0 & 0 & 0 & -61 & -89 & +6 & -61 & -89 & +6 \\
\hline & $\operatorname{LSD}_{\mathrm{N} \text {-fixed }}$ & $9 * * *$ & & & & & & & & & & & & & & \\
\hline & $\mathrm{LSD}_{\mathrm{N} \text {-soy grain }}$ & $40^{* *}$ & & & & & & & & & & & & & & \\
\hline & $\mathrm{LSD}_{\mathrm{N} \text {-bal. Soy grain removed }}$ & $9 * * *$ & & & & & & & & & & & & & & \\
\hline & LSD $_{\mathrm{N} \text {-bal. Soy grain + Maize Grain Removed }}$ & $12 * *$ & & & & & & & & & & & & & & \\
\hline \multirow[t]{8}{*}{ Lubino } & D1 & 39 & 72 & 55 & 42 & 60 & 60 & 59 & 75 & 76 & -3 & 12 & -5 & -62 & -63 & -81 \\
\hline & $\mathrm{D} 2$ & 51 & 100 & 78 & 54 & 120 & 72 & 61 & 59 & 62 & -3 & -20 & +6 & -64 & -79 & -56 \\
\hline & D3 & 75 & 122 & 90 & 66 & 138 & 90 & 50 & 49 & 50 & +9 & -16 & 0 & -41 & -65 & -50 \\
\hline & SS & 86 & 100 & 123 & 78 & 138 & 132 & 0 & 0 & 0 & +8 & -38 & -9 & +8 & -38 & -9 \\
\hline & $\operatorname{LSD}_{\mathrm{N} \text {-fixed }}$ & $6^{* * *}$ & & & & & & & & & & & & & & \\
\hline & $\mathrm{LSD}_{\mathrm{N} \text {-soy grain }}$ & $20 * *$ & & & & & & & & & & & & & & \\
\hline & $\mathrm{LSD}_{\mathrm{N} \text {-bal. Soy grain removed }}$ & $4 * * *$ & & & & & & & & & & & & & & \\
\hline & LSD $_{\mathrm{N} \text {-bal. Soy grain + Maize Grain Removed }}$ & $5 * * *$ & & & & & & & & & & & & & & \\
\hline
\end{tabular}

Note. $\mathrm{v}=$ soybean variety, where $\mathrm{v} 1=$ Namsoy $4 \mathrm{~m} ; \mathrm{v} 2=\mathrm{SC}$ Squire and $\mathrm{v} 3=\mathrm{TGx} 1987-18 \mathrm{~F} ; \mathrm{LSD}=$ Least significant difference between means, ${ }^{* *} P<0.01 ; * * * P<0.001$.

\subsection{Land Equivalent Ratio of Intercropping Systems}

All planting densities (D1, D2 and D3) for the three soybean varieties were lying above the linear line of sole maize and its corresponding soybean variety grown as sole crop, indicating an advantage of intercropping (Figure 2). Across sites and seasons, LER figures were highest in D2 with SC Squire, high in D2 with Namsoy 4 $\mathrm{m}$ and lower in D3 with TGx1987-18F. 


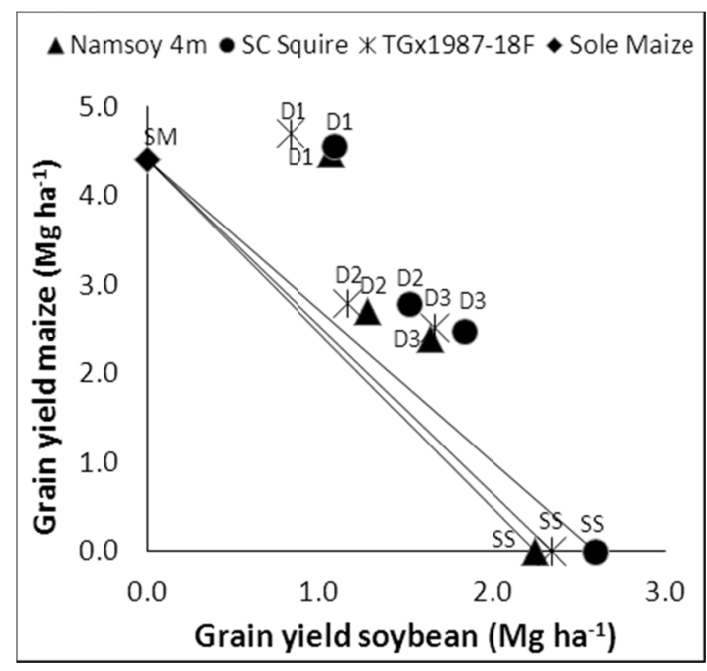

A: Manyala, short rainy season

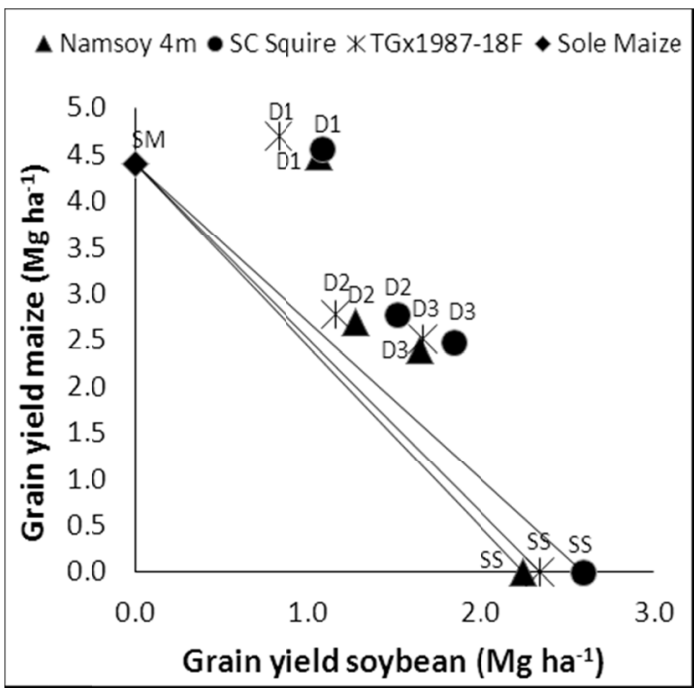

C: Manyala long rainy season

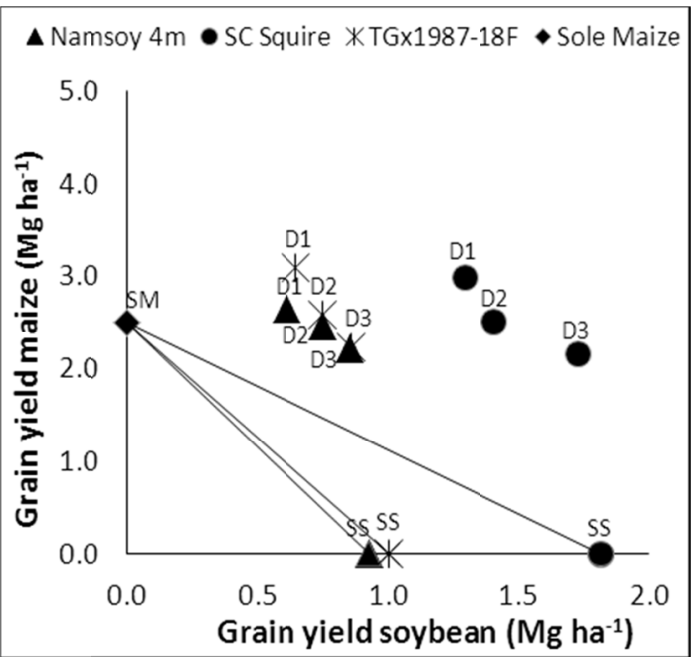

B: Lubino short rainy season

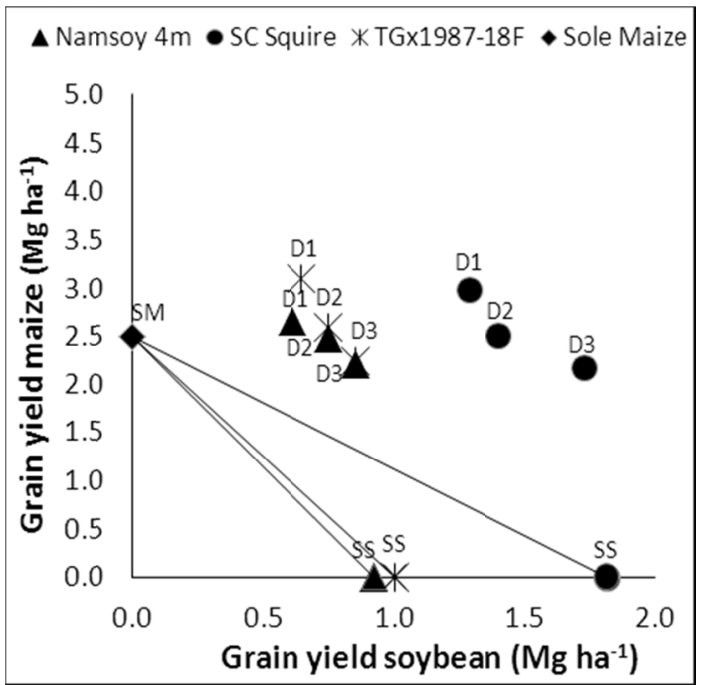

D: Lubino long rainy season

Figure 2. Relationships of maize and soybean grain yield in the intercrops and sole crops per season and site

\section{Discussion}

\subsection{Performance of Crops at Experimental Sites and Seasons}

Biomass yield, N-accumulation, N-fixed and yield of both maize and soybean were high at Manyala site and low at Lubino site. At both sites, the rainfall patterns during the experimental period followed similar trend and were more at Lubino in the short rainy season of 2013 and in the long rainy season of 2014. The observed poor crop performance at Lubino site could be attributed to soil acidity $(\mathrm{pH}<5.5)$ and associated large exchangeable Al $\left(700>\mathrm{mg} \mathrm{kg}^{-1}\right)$ (Table 1). High levels of exchangeable Al reduce the availability of $\mathrm{P}$ by precipitation or adsorbing $\mathrm{P}$ and inhibit the root growth, resulting in lesser exploration of bulk soil and lesser uptake of water and nutrients by plats (Landon, 1991; Vanlauwe et al., 2015). It also reduces the degree of colonization by soil rhizobia (Giller, 2001). These consequences, taken together, may have decreased biomass accumulation, which is the key for nitrogen fixation and grain yield of legumes. A number of studies have highlighted the challenge of high Al levels in soils across Western Kenya, where crops are responding poorly to N, P, and K fertilizers (Keino et al., 2015; Kihara et al., 2016; Tittonell, Vanlauwe, Leffelaar, Rowe, \& Giller, 2005). Such soils (referred to as non-responsive) are common in the densely populated areas like Lubino, where minimal inorganic and/or 
organic inputs are in short supply. Although the current results are based on few sites, they support the need for tailoring soil and crop management practices to site-specific conditions to increase crop productivity in smallholder farms in SSA (Giller, Schilt, \& Franke, 2013).

Soybeans accumulated more biomass and fixed more $\mathrm{N}$ in the short rainy season compared to long rainy season (Tables 3 and 4). This may be due to favorable temperatures and soil moisture conditions that prevailed in the short rainy season when the crop was at vegetative growth stage. According to Jaetzold and Schmidt (2005), temperatures in Western Kenya vary between 25 and $29^{\circ} \mathrm{C}$ in the short rainy season, the optimal temperatures for soybean growth (Nteranya Sanginga, 2003). Poor soybean grain yield in the short rainy season could have been caused, in large part by moisture stress caused by dry spells that occurred mid-November through December (Figures 1a and 1b). At the beginning of dry spells, Namsoy 4m and SC Squire were at R4 (seed filling stage) and TGx1987-18F at R1 (flowering stage) reproductive stage. In soybean, soil-water deficit at reproductive stage results in increased flower abortion, reduced pod number, reduced grain per pod, and the size of the grain, which affect negatively the grain yields of the crop (Frederick, Camp, \& Bauer, 2001; Purcell \& King, 1996).

\subsection{Performance of Soybean in the Intercrops}

The effect of intercropping three varieties of soybean with maize were significant for biomass yield, $\mathrm{N}$-accumulation, amount of $\mathrm{N}$-fixed and grain yield of both crops. The observed higher biomass and $\mathrm{N}$-accumulation of soybean in $\mathrm{D} 3$ relative to $\mathrm{D} 2$ and $\mathrm{D} 1$, and $\mathrm{D} 2$ relative to $\mathrm{D} 1 \mathrm{might}$ be associated with higher soybean plant population. Intercropping of maize and soybean at D3, is equivalent to reducing maize plant population to half the recommendation (53.000 to 24.240 plants per ha) and soybean plant population to two third the recommendation (444.440 to 363.630 plants per ha). Our results agree with those of Zhang et al. (2015) who reported higher biomass accumulation and $\mathrm{N}$ uptake in maize-soybean intercrop ratio of 1:3, compared to the ratio 1:1. Good performance of soybean at low population of maize may be attributed to the wide space available between alternate maize lines in intercropping leading to increased light use efficiency and enhanced photosynthesis of soybean.

Across plant densities, sites and seasons, the soybean variety TGx1987-18F accumulated more biomass and nitrogen and fixed more $\mathrm{N}$ than the rest of varieties. These results agree with Vanlauwe, Mukalama, Abaidoo, \& Sanginga (2011) who reported a range of soybean total biomass of 1.7 to $4.5 \mathrm{Mg} \mathrm{ha}^{-1}$ in Vihiga district, Western Kenya. In their study, long maturing varieties were found to accumulate more biomass and fix more $\mathrm{N}$ than the short maturing varieties. Long maturing cultivars are known to grow slowly and take this advantage to absorb and utilize more nutrients and solar energy and fix more $\mathrm{N}$ that is converted to plant tissues (Giller, 2001). Rusinamhodzi, Corbeels, Nyamangara, \& Giller (2012) reported similar observations when pigeon pea (Cajanus cajan) varieties with different maturity periods were evaluated under intercrop with maize in northern Mozambique.

The N-fixed in SS was not significantly different from $\mathrm{N}$-fixed in D3, but it was $50 \%$ and $22 \%$ higher than the $\mathrm{N}$-fixed in D1 and D2 respectively. The amount of $\mathrm{N}$-fixed in SS was within the range of 18 to $95 \mathrm{~kg} \mathrm{~N} \mathrm{ha}^{-1}$ observed by Osunde et al. (2003) in various farms in Nigeria. The use of universal $B$ values and a reference crop with different root-structure from a legume crop tested is reported to influence the calculations of \%Ndfa, especially when the $\delta^{15} \mathrm{~N}$ of reference is lower than the $\delta^{15} \mathrm{~N}$ of a legume plant (Giller, 2001). In our study, the $\delta^{15} \mathrm{~N}$ of reference plant was $4.67 \%$ for Manyala site and $4.42 \%$ for Lubino site, almost double the $\delta^{15} \mathrm{~N}$ recorded in soybeans samples, suggesting that the $B$ value and the reference crop used were appropriate (Unkovich et al., 2008). However, the reported quantities of $\mathrm{N}$-fixed in the present study could be an underestimation because did not account for the belowground contributions, comprising of $\mathrm{N}$ associated with roots, nodules and rhizodeposition via exudates and decaying root cells and hyphae, which is estimated to be $31 \%$ of $\mathrm{N}$-fixed at pod-filling stage (Ofosu-Budu et al., 1990). Other researchers, accounting for the $\mathrm{N}$-fixed in the belowground plant parts, have reported higher amounts of N-fixed. For instance, Eaglesham, Ayanaba, Rao, and Eskew (1982) reported $\mathrm{N}$-fixed by soybean of 114 to $188 \mathrm{~N} \mathrm{~kg} \mathrm{ha}^{-1}$ per season, and Nteranya Sanginga (2003) of 24 to $168 \mathrm{~kg} \mathrm{~N}$ $\mathrm{ha}^{-1}$ per season.

\subsection{Soybean and Maize Grain Yield}

Soybean grain yield ranged between 0.1 and $1.7 \mathrm{Mg} \mathrm{ha}^{-1}$ in the intercrops and 0.4 to 2.6 in SS. Kihara, Martius, Bationo, and Vlek (2011) had reported similar maize yields when soybean was intercropped or rotated with maize. SC Squire produced more grains because of its high yield potential, associated with many pods per plant, large and heavy grains, when compared to TGx1987-18F and Namsoy 4m. High yields in SC Squire, relative to other soybean varieties, have also been reported in other locations (Woomer et al., 2014), where SC Squire was 
identified among the best varieties in terms of grain yield in different agro-ecological zones in Southern, Central and in East Africa.

Although maize yield was low than reported elsewhere in SSA, it was within the range (0.6 to $\left.5.0 \mathrm{Mg} \mathrm{ha}^{-1}\right)$ reported in western Kenya (Wambugu, Mathenge, Auma, \& VanRheenen, 2012). The observed lower yields of maize with increasing soybean population can be attributed to a reduction in maize plant population as in most cases no significant differences were detected between D1 and SM, treatments which had the same maize plant population. The tall nature of maize in relation to soybean and its more widespread rooting system might have favored maize in D1. Dolijanović, Kovačević, Oljača, and Simić (2009) showed that, in the intercrops of soybean and maize, the maize component, which has often fast growth rate, height advantage and more widespread rooting system gives it an advantage in the competition with the associated soybean. The observed consistent, but slight increase in maize yield under D1, relative to SM in the long rainy season, may be due to N obtained through nitrogen fixation from associated soybean. It has been reported cereal crops can benefit for symbiotic N-fixed by the legume crop grown as intercrop through N-transfer (Wilson, Giller, \& Jefferson, 1991). Such performances of component crops in intercropping were also observed by Fujita et al. (1992); Layek et al. (2014). The N-transfer is considered to occur through root excretion, $\mathrm{N}$ leached from leaves and leaf fall (Fujita et al., 1992).

\subsection{Nitrogen Balances of Intercrops}

Nitrogen balances of crop fields that include grain legumes vary widely and are affected by site conditions, grain harvest and $\mathrm{N}$ input (Giller, 2001). Although in the present study the $\mathrm{N}$ obtained from $\mathrm{N}_{2}$ fixation ranged between 39 and $168 \mathrm{~kg} \mathrm{ha}^{-1} \mathrm{yr}^{-1}$ (Table 7), this could not turn the $\mathrm{N}$ balances into positive one. Similar soybean $\mathrm{N}$ balances have been reported in Argentina, Brazil, China, Canada and Thailand (Salvagiotti et al., 2008) and in Nigeria (Singh, Carsky, Lucas, \& Dashiell, 2003). In their review of biological nitrogen fixation studies that had been conducted between 1999 and 2006, (Salvagiotti et al., 2008) observed that the amount of N-fixed by soybean was, in most cases, insufficient to replace all the $\mathrm{N}$ removed in harvested grain. Overall, planting late maturing variety TGx1987-18F resulted in net addition, or less $\mathrm{N}$ removal of $\mathrm{N}$ from the soils, while the intermediate maturing variety SC Squire resulted in net N removal from the soil. Similar to the present study, Singh et al. (2003) also obtained more negative $\mathrm{N}$ balance values for early and intermediate maturing soybean varieties when compared to late maturing varieties. The short and intermediate maturing varieties are known to efficiently translocate $\mathrm{N}$ to the grain, thus leaving behind only a small proportion of $\mathrm{N}$ in the stover ( $\mathrm{N}$ Sanginga, Abaidoo, Dashiell, Carsky, \& Okogun, 1996). Assuming 31\% N contribution of below ground, the values of N balances in D1, D2 and D3 become less negative when only soybean grain is removed from the field. However, after removal of maize grain, net $\mathrm{N}$ balances of intercrops became more negative suggesting that in less productive soils, combinations of legume intercropping, and mineral $\mathrm{N}$ fertilizer application would be the best option.

\subsection{Efficiency of Intercropping Systems}

All the intercrops had LER greater than 1 suggesting that at all planting densities, maize and soybean complemented each other mutually in the utilization of resources. The observed decrease in LER values with increasing density of soybean suggest decreased efficiency in land resource utilization with increasing density of soybean. Zhang et al. (2015) had observed LER reductions in soybean intercropped with maize in Northern China and associated the LER depression to increase interspecific completion at higher soybean population. With the exception of Lubino site in the short rainy season, greater advantage of intercropping maize with soybean was obtained with variety SC Squire, closely followed by Namsoy $4 \mathrm{~m}$ in D2. This intercropping pattern could be an effective way of optimizing soybean and maize production in areas like Western Kenya where farmers are experiencing reduction in the amount of land available due to the rapid increase in human population. The high grain yields obtained at Manyala did not translate into higher LER values, suggesting that the LER was not influenced by the quantity of grain yields obtained in the location, but by the ratios of grain yields of maize and soybean in the intercrops and in sole crop. Although D3 performed almost equally as SS in terms of biomass accumulation, N-accumulation, N-fixed and soybean grain yield, it had lower LER when both soybean and maize yield were considered (section 3.6), making it difficult to be adopted by smallholder if maize is a major crop.

\section{Conclusions}

Above ground biomass, $\mathrm{N}$-accumulation and $\mathrm{N}$-fixed was higher in $\mathrm{D} 3$ with the long maturing soybean variety TGx1987-18F, while higher grain yield was recorded in D3 with SC Squire, a variety with intermediate growth duration. An increase in the population of soybean in the intercrops implied a reduction in maize grain yield, but 
improved the $\mathrm{N}$ balances, when soybean and maize grains were removed from the system. LER figures were above unity under all intercrop combinations, but it decreased with increasing density of soybean. Greater advantage of intercropping maize with soybean was obtained with SC Squire, closely followed by Namsoy $4 \mathrm{~m}$ and in D2. Small scale farmers in Western Kenya, and those living in areas with similar conditions in the highlands of East and Central Africa, can take greater advantage of biological nitrogen fixation by adopting 1:2 maize soybean intercropping system, using the intermediate growth types of soybean. Owing to the fact that the $\mathrm{N}$-fixed in the intercrop cannot compensate for the entire $\mathrm{N}$ harvested in the maize grain, this practice should be combined with (i) the application of mineral $\mathrm{N}$ targeted to maize (ii) application of fertilizers especially blended for legumes (e.g. SYMPAL) to supply secondary and micronutrients, (iii) returning to the field the soybean residues after removal of grain, (iv) liming of soil to increase the $\mathrm{pH}$ and reduce Al toxicity and (v) management of soil and crop to reduce drought stress.

\section{Acknowledgements}

This study was financially supported by Alliance for Green Revolution in Africa (AGRA) and International Institute of Tropical Agriculture (IITA) through the Bill and Melinda Gates Foundation-funded N2Africa project. John Mukalama of International Centre for Tropical Agriculture (CIAT), Maseno station, is thanked for support in the analysis of micronutrients in the experimental soils. Farmers in Manyala and Lubino villages, where the research was conducted, are equally thanked for active participation in the study, especially those who offered their farms for the experiments. This study was part of the first author's work in pursuit of MSc. degree in Sustainable Soil Resource Management at the University of Nairobi, Kenya.

\section{References}

Agegnehu, G., Ghizaw, A., \& Sinebo, W. (2008). Yield potential and land-use efficiency of wheat and faba bean mixed intercropping. Agronomy for sustainable development, 28(2), 257-263. https://doi.org/10.1051/ agro:2008012

Anglade, J., Billen, G., \& Garnier, J. (2015). Relationships for estimating N2 fixation in legumes: Incidence for $\mathrm{N}$ balance of legume-based cropping systems in Europe. Ecosphere, 6(3), 1-24. https://doi.org/10.1890/ ES14-00353.1

Banik, P., Sasmal, T., Ghosal, P., \& Bagchi, D. (2000). Evaluation of Mustard (Brassica compestris Var. Toria) and Legume Intercropping under 1:1 and 2:1 Row-Replacement Series Systems. Journal of Agronomy and Crop Science, 185(1), 9-14. https://doi.org/10.1046/j.1439-037X.2000.00388.x

Belel, M. D., Halim, R., Rafii, M., \& Saud, H. (2014). Intercropping of corn with some selected legumes for improved forage production: A review. Journal of Agricultural Science, 6(3), 48. https://doi.org/10.5539/ jas.v6n $3 \mathrm{p} 48$

Biabani, A., Hashemi, M., \& Herbert, S. (2012). Agronomic performance of two intercropped soybean cultivars. International Journal of Plant Production, 2(3), 215-222. https://doi.org/10.22069/ijpp.2012.614

Chianu, J. N., Nkonya, E. M., Mairura, F., Chianu, J. N., \& Akinnifesi, F. (2010). Biological nitrogen fixation and socioeconomic factors for legume production in sub-Saharan Africa: A review. Agronomy for Sustainable Development, 31(1), 139-154. https://doi.org/10.1051/agro/2010004

Dolijanović, Ž., Kovačević, D., Oljača, S., \& Simić, M. (2009). Types of interactions in intercropping of maize and soya bean. Journal of Agricultural Sciences, Belgrade, 54(3), 179-187. https://doi.org/10.2298/ JAS0903179D

Dwivedi, A., Dev, I., Kumar, V., Yadav, R. S., Yadav, M., Gupta, D., ... Tomar, S. (2015). Potential role of maize-legume intercropping systems to improve soil fertility status under smallholder farming systems for sustainable agriculture in India. International Journal of Life Sciences Biotechnology and Pharma Research, 4(3), 145-157.

Eaglesham, A., Ayanaba, A., Rao, V. R., \& Eskew, D. (1982). Mineral N effects on cowpea and soybean crops in a Nigerian soil. Plant and Soil, 68(2), 183-192. https://doi.org/10.1007/BF02373703

Egbe, O. (2010). Effects of plant density of intercropped soybean with tall sorghum on competitive ability of soybean and economic yield at Otobi, Benue State, Nigeria. Journal of Cereals and Oilseeds, 1(1), 1-10.

Frederick, J. R., Camp, C. R., \& Bauer, P. J. (2001). Drought-Stress Effects on Branch and Mainstem Seed Yield and Yield Components of Determinate Soybean South Carolina Agric. Exp. Stn. Technical Contribution no. 4599. Crop Science, 41(3), 759-763. https://doi.org/10.2135/cropsci2001.413759x 
Fujita, K., Ofosu-Budu, K., \& Ogata, S. (1992). Biological nitrogen fixation in mixed legume-cereal cropping systems. Plant and Soil, 141(1-2), 155-175. https://doi.org/10.1007/BF00011315

Fukai, S., \& Trenbath, B. (1993). Processes determining intercrop productivity and yields of component crops. Field Crops Research, 34(3-4), 247-271. https://doi.org/10.1016/0378-4290(93)90117-6

Giller, K. E. (2001). Nitrogen fixation in tropical cropping systems. CAB International. https://oi.org/10.1079/ 9780851994178.0000

Giller, K. E., Schilt, C., \& Franke, A. (2013). N2Africa: Putting nitrogen fixation to work for smallholder farmers in Africa. Retrieved from http:/www.n2africa.org/sites/n2africa.org/files/N2Africa\%20Podcaster\% 2047.pdf

He, X., Xu, M., Qiu, G. Y., \& Zhou, J. (2009). Use of 15N stable isotope to quantify nitrogen transfer between mycorrhizal plants. Journal of Plant Ecology, 2(3), 107-118. https://doi.org/10.1093/jpe/rtp015

Heuze, V., Tran, G., \& Delagarde, R. (2014). African couch grass (Digitaria abyssinica). Feedipedia (pp. np). Inra-Cirad-AFZ-FAO. Retrieved from https://hal.archives-ouvertes.fr/hal-01210898

Høgh-Jensen, H., \& Schjoerring, J. K. (2001). Rhizodeposition of nitrogen by red clover, white clover and ryegrass leys. Soil Biology and Biochemistry, 33(4), 439-448. https://doi.org/10.1016/S0038-0717 (00)00183-8

Jaetzold, R., \& Schmidt, H. (2005). Farm management Handbook of Kenya Vol. II-Natural conditions and farm management information-Vol. II, East Kenya (Eastern and Coast). Ministry of Agriculture, Nairobi, Kenya.

Jin, J., Liu, X., Wang, G., \& Herbert, S. (2003). A comparative study on physiological characteristics during reproductive growth stage in different yielding types and maturities of soybean. Zuo Wu Xue Bao, 30(12), 1225-1231.

Juma, C., Tabo, R., Wilson, K., \& Conway, G. (2013). Innovation for sustainable intensification in Africa. London: The Montpellier Panel, Agriculture for Impact.

Keating, B., \& Carberry, P. (1993). Resource capture and use in intercropping: Solar radiation. Field Crops Research, 34(3-4), 273-301. https://doi.org/10.1016/0378-4290(93)90118-7

Keino, L., Baijukya, F., Ng'etich, W., Otinga, A. N., Okalebo, J. R., Njoroge, R., \& Mukalama, J. (2015). Nutrients Limiting Soybean (Glycine max L.) Growth in Acrisols and Ferralsols of Western Kenya. PloS One, 10(12), e0145202. https://doi.org/10.1371/journal.pone.0145202

Kihara, J., Martius, C., Bationo, A., \& Vlek, P. L. (2011). Effects of tillage and crop residue application on soybean nitrogen fixation in a tropical ferralsol. Agriculture, 1(1), 22-37. https://doi.org/10.3390/agriculture 1010022

Kihara, J., Nziguheba, G., Zingore, S., Coulibaly, A., Esilaba, A., Kabambe, V., ... Huising, J. (2016). Understanding variability in crop response to fertilizer and amendments in sub-Saharan Africa. Agriculture, Ecosystems \& Environment, 229, 1-12. https://doi.org/10.3390/agriculture1010022

Landon, J. (1991). Booker tropical soil manual: A handbook for soil survey and agricultural land evaluation in the tropics and subtropics (p. 487). Joh Whiley \& Sons, Inc., New York.

Layek, J., Shivakumar, B., Rana, D., Munda, S., Lakshman, K., Das, A., \& Ramkrushna, G. (2014). Soybean-cereal intercropping systems as influenced by nitrogen nutrition. Agronomy Journal, 106(6), 1933-1946. https://doi.org/10.2134/agronj13.0521

Ledgard, S., Giller, K., \& Bacon, P. (1995). Atmospheric N2 fixation as an alternative N source. Nitrogen Fertilization in the Environment, 443-486.

Mahieu, S., Escarré, J., Brunel, B., Méjamolle, A., Soussou, S., Galiana, A., \& Cleyet-Marel, J.-C. (2014). Soil nitrogen balance resulting from $\mathrm{N}$ fixation and rhizodeposition by the symbiotic association Anthyllis vulneraria/Mesorhizobium metallidurans grown in highly polluted $\mathrm{Zn}, \mathrm{Pb}$ and $\mathrm{Cd}$ mine tailings. Plant and Soil, 375(1-2), 175-188. https://doi.org/10.1007/s11104-013-1941-4

Maskey, S., Bhattarai, S., Peoples, M., \& Herridge, D. (2001). On-farm measurements of nitrogen fixation by winter and summer legumes in the Hill and Terai regions of Nepal. Field Crops Research, 70(3), $209-221$. https://doi.org/10.1016/S0378-4290(01)00140-X

Mehlich, A. (1984). Mehlich 3 soil test extractant: A modification of Mehlich 2 extractant. Communications in Soil Science \& Plant Analysis, 15(12), 1409-1416. https://doi.org/10.1080/00103628409367568 
Mucheru-Muna, M., Pypers, P., Mugendi, D., Kung'u, J., Mugwe, J., Merckx, R., \& Vanlauwe, B. (2010). A staggered maize-legume intercrop arrangement robustly increases crop yields and economic returns in the highlands of Central Kenya. Field Crops Research, 115(2), 132-139. https://doi.org/10.1016/j.fcr.2009. 10.013

Muoneke, C., Ogwuche, M., \& Kalu, B. (2007). Effect of maize planting density on the performance of maize/soybean intercropping system in a guinea savannah agroecosystem. African Journal of Agricultural Research, 2(12), 667-677.

Nandwa, S. M., \& Bekunda, M. (1998). Research on nutrient flows and balances in East and Southern Africa: State-of-the-art. Agriculture, Ecosystems \& Environment, 71(1), 5-18. https://doi.org/10.1016/S0167-8809 (98)00128-5

Odendo, M., Bationo, A., \& Kimani, S. (2011). Socio-economic contribution of legumes to livelihoods in Sub-Saharan Africa. Fighting poverty in Sub-Saharan Africa: The multiple roles of legumes in Integrated Soil Fertility Management (pp. 27-46): Springer. https://doi.org/10.1007/978-94-007-1536-3_2

Ofosu-Budu, K., Fujita, K., \& Ogata, S. (1990). Excretion of ureide and other nitrogenous compounds by the root system of soybean at different growth stages. Plant and Soil, 128(2), 135-142. https://doi.org/10.1007/ BF00011102

Okalebo, J. R., Gathua, K. W., \& Woomer, P. L. (1993). Laboratory methods of soil and plant analysis: A working manual. Tropical Soil Biology and Fertility Programme Nairobi, Kenya.

Osunde, A., Bala, A., Gwam, M., Tsado, P., Sanginga, N., \& Okogun, J. (2003). Residual benefits of promiscuous soybean to maize (Zea mays L.) grown on farmers' fields around Minna in the southern Guinea savanna zone of Nigeria. Agriculture, Ecosystems \& Environment, 100(2), 209-220. https://doi.org/ 10.1016/S0167-8809(03)00197-X

Purcell, L. C., \& King, C. A. (1996). Drought and nitrogen source effects on nitrogen nutrition, seed growth, and yield in soybean. Journal of Plant Nutrition, 19(6), 969-993. https://doi.org/10.1080/01904169609365173

Rao, M., \& Willey, R. (1980). Evaluation of yield stability in intercropping: Studies on sorghum/pigeonpea. Experimental Agriculture, 16(02), 105-116. https://doi.org/10.1017/S0014479700010796

Rerkasem, B., Rerkasem, K., Peoples, M., Herridge, D., \& Bergersen, F. (1988). Measurement of $\mathrm{N}_{2}$ fixation in maize (Zea mays L.) and ricebean (Vigna umbellata [Thunb.] Ohivi and Ohashi) intercrops. Plant and soil, 108, 125-135. https://doi.org/10.1007/BF02370107

Rusinamhodzi, L., Corbeels, M., Nyamangara, J., \& Giller, K. E. (2012). Maize-grain legume intercropping is an attractive option for ecological intensification that reduces climatic risk for smallholder farmers in central Mozambique. Field Crops Research, 136, 12-22. https://doi.org/10.1016/j.fcr.2012.07.014

Salvagiotti, F., Cassman, K. G., Specht, J. E., Walters, D. T., Weiss, A., \& Dobermann, A. (2008). Nitrogen uptake, fixation and response to fertilizer $\mathrm{N}$ in soybeans: A review. Field Crops Research, 108(1), 1-13. https://doi.org/10.1016/j.fcr.2008.03.001

Sanginga, N. (2003). Role of biological nitrogen fixation in legume based cropping systems; a case study of West Africa farming systems. Plant and Soil, 252(1), 25-39. https://doi.org/10.1023/A:1024192604607

Sanginga, N., Abaidoo, R., Dashiell, K., Carsky, R., \& Okogun, A. (1996). Persistence and effectiveness of rhizobia nodulating promiscuous soybeans in moist savanna zones of Nigeria. Applied Soil Ecology, 3(3), 215-224. https://doi.org/10.1016/0929-1393(95)00089-5

Singh, A., Carsky, R., Lucas, E., \& Dashiell, K. (2003). Soil N balance as affected by soybean maturity class in the Guinea savanna of Nigeria. Agriculture, Ecosystems \& Environment, 100(2), 231-240. https://doi.org/ 10.1016/S0167-8809(03)00193-2

Smith, M., \& Francis, C. (1986). Breeding for multiple cropping systems. Multiple cropping systems. MacMillan Publishing Company, New York.

Somasegaran, P., \& Hoben, H. J. (2012). Handbook for rhizobia: Methods in legume-Rhizobium technology. Springer Science \& Business Media.

Stern, W. (1993). Nitrogen fixation and transfer in intercrop systems. Field Crops Research, 34(3-4), 335-356. https://doi.org/10.1016/0378-4290(93)90121-3 
Tittonell, P., Vanlauwe, B., Leffelaar, P., Rowe, E. C., \& Giller, K. E. (2005). Exploring diversity in soil fertility management of smallholder farms in western Kenya: I. Heterogeneity at region and farm scale. Agriculture, Ecosystems \& Environment, 110(3), 149-165. https://doi.org/10.1016/j.agee.2005.04.001

Tsubo, M., Walker, S., \& Mukhala, E. (2001). Comparisons of radiation use efficiency of mono-/inter-cropping systems with different row orientations. Field Crops Research, 71(1), 17-29. https://oi.org/10.1016/ S0378-4290(01)00142-3

Unkovich, M., Herridge, D., Peoples, M., Cadisch, G., Boddey, B., Giller, K., ... Chalk, P. (2008). Measuring plant-associated nitrogen fixation in agricultural systems. Australian Centre for International Agricultural Research (ACIAR).

Vanlauwe, B., Descheemaeker, K., Giller, K., Huising, J., Merckx, R., Nziguheba, G., ... Zingore, S. (2015). Integrated soil fertility management in sub-Saharan Africa: unravelling local adaptation. Soil, 1(1), 491. https://doi.org/10.5194/soil-1-491-2015

Vanlauwe, B., Mukalama, J., Abaidoo, R., \& Sanginga, N. (2011). Soybean Varieties, Developed in Lowland West Africa, Retain Their Promiscuity and Dual-Purpose Nature Under Highland Conditions in Western Kenya. Innovations as Key to the Green Revolution in Africa (pp. 133-144). Springer. https://doi.org/ $10.1007 \% 2 F 978-90-481-2543-2 \_12$

Waddington, S., Mekuria, M., Siziba, S., \& Karigwindi, J. (2007). Long-term yield sustainability and financial returns from grain legume-maize intercrops on a sandy soil in subhumid north central Zimbabwe. Experimental Agriculture, 43(04), 489-503. https://doi.org/10.1017/S0014479707005303

Wambugu, P., Mathenge, P., Auma, E., \& VanRheenen, H. (2012). Constraints to on-farm maize (Zea mays L.) seed production in western Kenya: Plant growth and yield. ISRN Agronomy, 2012. https://doi.org/10.5402/ $2012 / 153412$

Willey, R. (1979). Intercropping Its Importance and Research Needs Part 1. Competition and Yield Advantages. Field Crop Abstracts, 32, 1-10.

Willey, R., Natarajan, M., Reddy, M., Rao, M., Nambiar, P., Kannaiyan, J., \& Bhatnagar, V. (1983). Intercropping studies with annual crops. Better Crop for Food. Ciba Foundation Symposium 97, 14-16 Sept. 1982, Pitman, London,UK. https://doi.org/10.1002/9780470720783.ch7

Wilson, K. J., Giller, K. E., \& Jefferson, R. A. (1991). $\beta$-glucuronidase (GUS) operon fusions as a tool for studying plant-microbe interactions. Advances in Molecular Genetics of Plant-Microbe Interactions, 1, 226-229. https://doi.org/10.1007/978-94-015-7934-6_35

Woomer, P., Huising, J., Giller, K., Baijukya, F., Kantengwa, S., Vanlauwe, B., ... Abaidoo, R. (2014). N2Africa Final Report of the First Phase: 2009-2013.

Zhang , F., \& Li, L. (2003). Using competitive and facilitative interactions in intercropping systems enhances crop productivity and nutrient-use efficiency. Plant and Soil, 248(1), 305-312. https://doi.org/10.1023/ A:1022352229863

Zhang, Y., Liu, J., Zhang, J., Liu, H., Liu, S., Zhai, L., ... Yin, C. (2015). Row ratios of intercropping maize and soybean can affect agronomic efficiency of the system and subsequent wheat. PloS one, 10(6), e0129245. https://doi.org/10.1371/journal.pone.0129245

\section{Copyrights}

Copyright for this article is retained by the author (s), with first publication rights granted to the journal.

This is an open-access article distributed under the terms and conditions of the Creative Commons Attribution license (http://creativecommons.org/licenses/by/4.0/). 